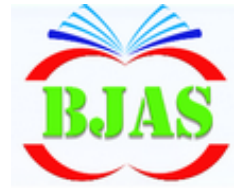

ISSN $1814-5868$
Available online at $\mathrm{http} / / / \mathrm{bjas}$. bajas.edu.iq https://doi.org/10.37077/25200860.2020.33.2.11 College of Agriculture, University of Basrah

\title{
Article Review: Camel Milk as an Amazing Remedy for Health Complications: A Review
}

\author{
Tahereh Mohammadabadi \\ Department of Animal Science, Faculty of Animal Science and Food Technology, Agricultural \\ Sciences and Natural Resources University of Khuzestan, Ahvaz, Iran \\ mohammadabadi@asnrukh.ac.ir
}

Received 30 March 2020; Accepted 18 June 2020; Available online 20 October 2020

\begin{abstract}
Camel milk has unique benefits for human health. Protein is the main component which gives special properties to camel milk and effectively influences its nutritional value. Due to lack of $\beta$-lactoglobulin in the camel milk, it may be as a proper alternative for human milk. Camel milk is rich in vitamins $\mathrm{C}$, manganese and iron. There are high amount of unsaturated fatty acids, immunoglobulin's, insulin like protein and protective enzymes like lactoferrin and lysozyme in the camel milk. The lactoferrin has the effects or properties of antibacterial, antiviral and anti-inflammatorry. Also, it has been proven that camel milk has beneficial application in disorders of stomach and intestinal, food allergy, diabetes mellitus, cancer, autism, and viral hepatitis. Camel milk containing insulin like protein and may help to heal diabetes of Type 1 and 2 and gestational diabetes. It contains small size immunoglobulins which strengthens the immune system. In addition, camel milk reduces blood cholesterol amount, avoiding of psoriasis disease, healing of inflammation and improving of tuberculosis patients. Camel milk may be effective as unique miracle in many healthy issues of human and especially cardiovascular system. Therefore, it is not only food, but also it is as amazing remedy for treatment and healthy issues.
\end{abstract}

Key words: Camel milk, Health, Lactoferrin, Medicinal values.

\section{Introduction}

Camel milk as a unique source of nutrients and vitamin $\mathrm{C}$, prepares about $30 \%$ of the annual calorie in the diet of pastoral community (Farah et al., 1993). Camel milk contains fat, cholesterol, and lactose of camel milk is lower than bovine milk, but minerals such as calcium, magnesium, iron, copper and zinc, and vitamins $\mathrm{A}$ and $\mathrm{C}$ are greater than bovine milk. It contains no $\beta$-lactoglobulin and low $\beta$-casein which are the allergic proteins in cow's milk (Shabo \& Yagil, 2005). Protective proteins of camel milk including lactoferrin, lactoperoxidase, lysozymes, immunoglobulins, $\mathrm{N}$-acetyl-§-glycosaminidases and peptidoglycan recognition protein have therapeutic properties (Shabo \& Yagil, 2005). Smaller size of nanobodies of camel milk prevent food allergy and enhance the immune system and inflammations (Shabo \& Yagil, 2005). 


\section{Mohammadabadi/ Basrah J. Agric. Sci., 33(2): 125-137, 2020}

Lactoperoxidase of camel milk acts against gram-positive and negative strains (Galali \& Al-Dmoor, 2019). Camel milk also contains higher amount of zinc that is important in the development and maintenance of normal function of immune system (Habib et al., 2013). Scientists believe in antibodies of camel milk could be effective against cancer cells, HIV, Alzheimer's and hepatitis C (Shabo \& Yagil, 2005; Habib et al., 2013). Camel milk has properties of regulatory and immunomodulatory on pancreases $\beta$ cells. Furthermore, camel milk has anti-malignant, antiplatelet and anti-thrombotic properties in addition to anti-bacterial and anti-viral properties (Elagamy et al., 2009).

Due to presence of insulin/insulin like protein, camel milk exhibits hypoglycemic effects, which can be beneficial in the healing of diabetic cases. Currently, it is proved that camel milk is effective against diabetes complications and heart failures (Shori, 2015). Also currently, it was intensively explored on antimicrobial effects of camel milk lactoferrin (Al-Majali et al., 2007). Furthermore, lactic acid bacteria of camel milk as probiotic are important for the gut health (Yateem et al., 2008). Camel milk has been cured partially autism subjects, food allergies, and crohn's problem (Shabo \& Yagil, 2005).

The current review presents therapeutic properties of camel milk according to the scientific documents and researches.

\section{Camel milk effects on diabetes}

Diabetes mellitus is one of the most common metabolic disorders that linked with cardiovascular diseases and kidney and liver failures (Wild et al., 2004). Camel milk contains insulin like proteins, which does not form coagulum in the acidic media of stomach that can be an effective alternative for insulin (Mohamad et al., 2009). In India the incidence risk of diabetes in people who use camel milk regularly, is much lower compared to others who don't use camel milk. Camel milk improves the glycemic control and decrease insulin resistance in diabetes patients (Sboui et al., 2010). It is detected high amount of insulin in camel milk (about 52 unit.litre $^{-1}$ ), and using of camel milk in diabetes patients causes to reduce blood sugar and required insulin (Agrawal et al., 2003). Camel milk improves obesity, inflammation, wounds, and oxidative stress damages as diabetes complications (Agrawal et al., 2007).

Therefore, camel milk and some its active matters influence pancreatic $\beta$-cells and insulin receptors function in the insulin-sensitive tissues, therefore increase insulin secretion (Ayoub et al., 2018).

Camel milk contains insulin like protein and amino acids is enriched with half-cysteine same with insulin, can be absorbed from intestine without destroying in the stomach (Shori, 2015). The reason is presence of fat micelles in camel milk that cover insulin, and transfer to circulatory system in the diabetic patients (Shamsia, 2009). Therefore; camel milk can control diabetes mellitus 1, high cholesterol level, liver and kidney disease, and wound healing. Daily drinking of camel milk may meet about $60 \%$ of the insulin in diabetic patients (Shori, 2015). Raw Camel milk has immunemodulatory effects on beta-cells of the pancreas, insulin receptor function and insulin secretion, and reduces insulin amount required 


\section{Mohammadabadi/ Basrah J. Agric. Sci., 33(2): 125-137, 2020}

in diabetes 1 patients (Agrawal et al., 2011; Ayoub et al., 2018).

Many recent researches revealed that consuming of whey proteins or peptides of camel milk enhanced healing of wounds in diabetic animals. The whey proteins of camel milk with anti-oxidative activity enhances the of immune cells proliferation and diabetic wounds healing (Ebaid et al., 2015; Aqiba et al., 2019)

The camel milk can normalize renal and liver failures in diabetic patients, that the alanine aminotransferase (ALT) and aspartate aminotransferase (AST) may recover 41 and 48\%, respectively (Hamad et al., 2011).

Hypoglycemia effects of camel milk improved kidney and liver function in nephropathy; proteinuria and cardiovascular challenge appear to be major complications in type 1 and 2 diabetes mellitus (Molitch et al., 2004).

Therefore, camel milk is safe in long-term control of glycemic that significantly reduce the required insulin doses in diabetic patients of type 1 (Aqiba et al., 2019). In India, diabetic juvenile treated with camel milk significantly reduced blood sugar (Agrawel et al., 2003).

It is concluded, camel milk can be utilized to cure type 2 diabetes and reduce the required insulin (in some cases the required insulin dose was zero), blood glucose and haemoglobin (Shori, 2015).

Therefore even if camel milk has significant effect in decreasing of blood glucose and required insulin, and improve diabetes problems, but it appears that more scientific studies are needed to confirm the effectiveness of camel milk for the treatment of diabetes.

\section{Camel milk on autism cases}

Autism spectrum disorder (ASD) is a sever malfunctions of neurodevelopment that are accompanied by failures in interactions of communication and social. In addition, high prevalence of gastrointestinal disease and mental retardation happens in autism cases (Bölte \& Poustka, 2002).

The increased production of reactive oxygen species and oxidative stress may lead to reduction of injury of brain cell, apoptosis and autism (Russo, 2009). Thus, the control of reactive oxygen production is important for cell function and they should be removed by antioxidants such as enzymes of glutathione peroxidase, catalase and superoxide dismutase (Al-Ayadhi \& Elamin, 2013).

Autistic children who using camel milk have had amazing improvements in their behavior (Al-Ayadhi \& Elamin, 2013). Camel milk decreases oxidative stress by alteration of antioxidant enzymes and nonenzymatic antioxidant, and improve autistic behaviors. The consumption of camel milk in autistic cases improved motor skills, language and social communication (Panwar et al., 2015).

Researchers reported possibly camel milk cause to immune system recovering, due to the immunoglobulins of camel milk; therefore brain damage would be prevented at early age by consumption of camel milk (Alavi et al., 2017). Wernery \& Yagil (2012) reported that the autism cases (children) have a better social condition and improve gut function after the consumption of camel milk.

Camel milk contains high vitamin $\mathrm{C}$, copper, zinc, iron and magnesium as strong antioxidants against free radicals (Kaskous, 


\section{Mohammadabadi/ Basrah J. Agric. Sci., 33(2): 125-137, 2020}

2016). Al-Ayadhi \& Elamin (2013) reported autism healing by camel milk could contribute to decreasing oxidative stress due to antioxidants such as vitamin $\mathrm{C}$, magnesium and zinc, where are essential for activities of antioxidant enzymes. In autism subjects, due to camel milk containing inflammation-inhibiting and hypoallergenic properties, also smaller size of antibodies can treat gastrointestinal problems and improve some autistic behaviors (Rasheed, 2011).

Lack of $\beta$-lactoglobulin, lower content of $\beta$ casein, and presence of protective proteins of camel milk enhance immune system and brain development (Galali \& Al-Dmoor, 2019).

\section{Anti-microbial effects of camel milk}

Camel immune system is different and stronger from all other mammalians. Camel milk IgGs do not have light chains (Gizachew et al., 2014). Due to specificity of camel immunoglobulins with having two heavy chains, they interact with active sites of tissues (Gizachew et al., 2014). As camel milk Igs are found in throughout lactation, combat autoimmune diseases by strengthen the immune system (Muylderman et al., 2001). Immunoglobulins of the camel milk are against tuberculosis bacteria and protect the body from infections of viral (Galali \& Al-Dmoor, 2019).

Therefore, camel milk contains various protective proteins and enzymes which have antibacterial and immunological properties (Farah, 1993). These protective proteins of camel milk including lysozymes that participate in immune system, and invade pathogens (Conesa et al., 2008). Immunoglobulins that protect body against infections; Lactoferrin that prevents undesirable microbial growth in gastrointestinal and alleviate primary immune system (Gizachew et al., 2014). Camel milk apparently contains much more lactoferrin than other ruminant milk. Camel milk lactoferrin is from 95 to $250 \mathrm{ml}^{-\mathrm{dl}^{-1}}$ which can inhibit the infectious microbe's growth (Morin et al., 1995). Lactoperoxidase can contribute to the defense system and has bactericidal activity on gram negatives. Activity of camel milk lactoperoxidase is about $2.23 \pm 0.01 \mathrm{U} \cdot \mathrm{ml}^{-1}$ of milk (Galali \& Al-Dmoor, 2019). Peptidoglycan recognition protein in camel milk by controlling metastasis and stimulating the host's immune response influences breast cancer; the highest amount of this enzyme found in camel milk (Gizachew et al., 2014).

$\mathrm{N}$-acetyl-§-glucosaminidase (NAGase) in the camel milk that enhances the activity of antibacterial-antiviral (Hoelzer et al., 1998).

Researchers have concluded that camel milk has beneficial effects on tuberculosis cases that resist to multidrugs (Alwan \& Tarhuni, 2000). The camel milk has antimicrobial activity against foodborne pathogens such as Listeria monocytogenes and E. coli O157:H7. But pasteurization of camel milk had no effect on antimicrobial activity (Ayyash, 2016). Lactoferrin of camel milk has anti-viral activity and inhibits the virus into the cells. The camel milk lactoferrin is very strong and inhibit Schistosoma mansoni (Redwan \& Tabll, 2007). Camel milk inhibits growth of E. coli, Klebsiella pneumonia, Clostridium species, Helicobacter pylori, Staphylococcus aureus, and Candida albicans. Also it acts against human immunodeficiency virus, infections of hepatitis B and C, cytomegalovirus, and herpes simplex virus-1 (Rasheed, 2017). Therefore according to studies, the most therapeutic 


\section{Mohammadabadi/ Basrah J. Agric. Sci., 33(2): 125-137, 2020}

effects of camel milk are due to lactoferrin and Immunogloloulins (Rasheed, 2017).

\section{Camel milk effects on food allergies}

Camel milk lacks $\beta$-lactoglobulin and a low and different $\beta$-casein, which is two powerful allergens in cow milk, makes the camel milk proper children suffering from milk allergies. Camel milk rapidly improved children who suffering severe food allergies (Restani et al., 1999). Also it is new protein source for allergic children to cow's milk (Panwar et al., 2015). But still it needs more researches to be clearer.

Additionally, immunoglobulin's camel milk is same to human milk, which improves allergic reactions to foods. Katz et al. (2008) revealed that $25 \%$ of allergic cases to cow milk, had allergies to camel milk.

Elagamy et al. (2009) found that $\operatorname{IgE}$ of children with allergy to cow's milk didn't react to camel milk (Stahl, 2005). Shabo \& Yagil (2005) investigated the camel milk effect on eight children with severe food allergies. The children consumed camel milk for two weeks, after 24 hours they have showed fewer symptoms and after four days all the symptoms disappeared. In all subjects, camel milk leads to rapid improvement in digestion of other foods. It is proved that camel milk immunoglobulin's have effective role in reducing allergic symptoms of children.

Eighty $\%$ of the children with allergy to foods, improved by using camel milk. These allergic children to cow's milk could safely consume camel milk. Children with severe allergies to food and milk, who no responded to any therapies, could improve after the consumption of camel milk, daily (Shabo \& Yagil, 2005).
Additional scientific researchers are needed to confirm the effectiveness of camel milk in healing of food allergies.

\section{Camel milk effects on skin health and treating psoriasis}

Camel milk contains $\alpha$-hydroxyl acids and is anti-aging which shed skin dead cells. Alphahydroxyl acids have important role to eliminate wrinkles and spots and improve dryness (Panwar et al., 2015). These acids are used by cosmetic industries for wrinkles and soften of skin (Babilas et al., 2012). In addition, liposomes of camel milk are beneficial for cosmetic ingredient (Choi et al., 2013). The application of camel milk crème containing $40 \%$ raw camel milk showed very good results in psoriasis patients. Itching, skin redness and dryness reduced when 20 patients with psoriasis were treated with $2 \mathrm{x}$ camel milk crème for four weeks, daily (Wernery, 2006).

Presence of high vitamin $\mathrm{C}$ in the camel milk as strong antioxidant has protective activity on skin tissue against free radicals and heals skin issues; wrinkles and dryness. Vitamin $\mathrm{C}$ has a key important in collagen synthesis, the growth of cells and blood vessels and strengthens skin firmness (Jilo \& Tegegne, 2016). Furthermore, following to camel milk consumption, some bioactive peptides that produced from digestion of camel milk protein are act as natural antioxidants and ACE inhibitors (Salami et al., 2011; Yagil, 2017).

\section{Camel milk against Hepatitis $\mathrm{C}$ and $\mathrm{B}$}

It is reported that the high lactoferrin of camel milk is as a primary drug against $\mathrm{HCV}$ infection and leads to complete inhibition of virus entry (Redwan \& Tabll, 2007). In addition to lactoferrin, camel milk $\mathrm{IgG}$ can recognize 


\section{Mohammadabadi/ Basrah J. Agric. Sci., 33(2): 125-137, 2020}

peptides of Hepatitis $\mathrm{C}$ virus in comparison with human IgG (El-Fakharany et al., 2012). In addition, camel milk can enhance the cellular immune responses, inhibits the replication of virus DNA and recovers chronic hepatitis B patients (Saltanat et al., 2009).

Redwan \& Tabll (2007) observed 88\% improvement in enzymes of alanine and aspartate aminotransferase in eighteen $\mathrm{HCV}$ patients who were fed with camel milk. About $50 \%$ of the patients noticeably showed improvement in fatigue. El-Fakharany et al. (2013) demonstrated that the camel milk lactoferrin effectively stop $\mathrm{HCV}$ entry and replication in infected HepG2 cells was more than lactoferrin of human, bovine, and sheep milk.

The protective and therapeutic effects of camel milk on liver induced injury of rats by ethanol explored by Darwish et al. (2012). Using of camel milk normalize liver enzymes, improved liver function, reduced serum triglycerides, hepatic malondealdehyde and TNF- $\alpha$ and apoptosis, as well as enhancement of total antioxidant capacity and the antioxidant defense system (Darwish et al., 2012).

The camel milk consumption for eight weeks recovered liver function, reduced hepatic fat and inflammatory infiltration and increased the activity of glutathione and catalase enzymes (Korish \& Arafah, 2013).

According to research, camel's milk was more effective than mare's milk in improving and normalizing of patient's status with chronic active hepatitis. It is proved that camel milk lactoferrin is stronger anti-viral than human and bovine milk lactoferrins (Redwan \& Tabll, 2007).
Camel milk contains casein that begins the apoptosis of HCV cells (Almahdy et al., 2011). High vitamin $\mathrm{C}$ of camel milk improves liver function (Gul et al., 2015). Also the antibodies in camel milk selectively control virus systems. Therefore, camel milk antibodies are about tenth of human antibodies size that makes more affinity to penetrate to the targeted antigens (Muyldermans et al., 2001).

\section{Camel milk as anti-cancer factor or nutrient}

Studies have proven that camel milk stop cancer cells through the activation of apoptotic pathways (Galali \& Al-Dmoor, 2019). High amounts of camel milk immunoglobulins, lactoferrins and iron - binding glycoprotein are antitumor matters, due to increasing RNA synthesis and the inhibition of protein kinases. Also camel milk lactoperoxidase possess antitumor activity. Peptidoglycan recognition protein in camel milk combat breast cancer by take over metastasis (Galali \& Al-Dmoor, 2019).

Camel milk markedly inhibited the cancer cells proliferation by $50 \%$ by activation of caspase-3 mRNA (Korashy et al., 2012), and exerts antioxidant with activity of DNA damage inhibitory (Habib et al., 2013). According to study of Gader \& Alhaider (2016); camel milk can remove cancer cells of hepatic, colon, lung, glioma cells and leukemia The active antibodies of camel milk are able to destroy cells of tumor (Levy et al., 2013). Additionally, camel milk have thrombolytic activity which inhibits fibrin formation, consequently inhibit the of tumor cells growth (Jilo \& Tegegne, 2016).

Also camel milk lactoferrin inhibit the in vitro proliferation of colon cancer cells and the DNA damage (Habib et al., 2013). 


\section{Mohammadabadi/ Basrah J. Agric. Sci., 33(2): 125-137, 2020}

Anti-tumor properties of camel milk are due to strong antimicrobial and anti-oxidative activities that reduce liver inflammation. The effects of antigenotoxic and anticytotoxic of camel milk inhibit micronucleated polychromatic erythrocytes (Salwa \& Lina, 2010). Although, camel milk lactoferrin, reduced cancer growth by $56 \%$, but further researches is needed to confirm camel milk lactoferrin on stopping cancer (Habib et al., 2013).

\section{Camel milk as anti-inflammatory and anti- arthritis agent}

Higher amount of camel milk lactoferrin has that removes free iron from joints of arthritic patients, therefore improves arthritic (Panwar et al., 2015). Camel milk lactoferrin activity has properties of cartilage protective, anti-arthritic and anti-inflammatory (Rasheed, 2017).

Camel milk has anti-inflammatory effects against infectious diseases. Furthermore, high level vitamin $\mathrm{C}$, zinc and magnesium are very essential to decrease oxidative stress (Al-Wabel et al., 2012).

\section{Camel milk effects on gastrointestinal failures}

\section{Diarrhea}

High concentration of anti-inflammatory proteins of camel milk have proper effects on the stomach and intestinal issues. The high content of unsaturated fatty acids and vitamins of camel milk improve carbohydrates metabolism. Moreover, the presence of Angiotensin I-converting enzyme in fermented camel milk improves the digestibility of the camel milk proteins (Alhaj et al., 2006; Quan et $a l ., 2008)$. Recent reports on the beneficial effects of camel milk on the digestive system health confirmed that camel milk has properties of anti-diarrhea in the children (Yagil, 2013). Camel milk is rich in anti-rotavirus antibodies, may be used to treat diarrhea by rotavirus contamination in children (Yagil, 2013).

\section{Lactose intolerance}

Studies on 25 patients with lactose intolerance that consumed camel milk have showed good results that camel milk is a suitable option for the lactose intolerant people (Cardoso et al., 2010). Lactose-intolerant patients easily digest camel milk (Mullaicharam, 2014). The reason is high concentration L-Lactate in camel milk in compared to cow milk that is rich in DLactate (Baubekova et al., 2015).

\section{Camel milk effects on blood cholesterol and cardiovascular diseases}

The fermented camel milk has hypocholesterolemic effects in rats, that mechanism is still unrecognized well (Elayan et al., 2008). But maybe, the interaction between bioactive peptides of camel milk and cholesterol decrease cholesterol (Li \& Papadopoulos, 1998). According to other researches, the presence of orotic acid produced from the nucleic acid metabolism is responsible for the lowering of cholesterol amount in rats and humans consumed camel milk (Kaskos, 2016).

The administration of camel milk for five weeks showed a significant decrease in the total cholesterol from 6.17 to $4.35 \mathrm{~m} \mathrm{mol.} \mathrm{l}^{-1}$ (Shori, 2015). Al-Numair (2010) concluded that the administration of camel milk for 45 days significantly decreased hyperlipidemia; total cholesterol, triacylglycerol's, free fatty acid, LDL, and VLDL in plasma, liver, heart and kidney towards normal levels. Also after 


\section{Mohammadabadi/ Basrah J. Agric. Sci., 33(2): 125-137, 2020}

consumption of camel milk, the content of HDL significantly improved. Other researcher's recently reported the hypocholesterolemic effect of fermented camel milk or Gariss (Ali et al., 2013). After using of camel milk for 6 months, the amounts of LDL and triacylglycerol's reduced in type 1 diabetic cases (Agrawal et al., 2009).

\section{Camel milk effects on tuberculosis and crohn patients}

There is a significant improvement of symptoms of tuberculosis through consumption of camel milk by drug-resistant patients. By administering of camel milk by 1 litre per day, consequently these patients didn't show cough, sputum and chest pain (Wernery \& Yagil, 2012). In addition, immunoglobulins of camel milk restore the immune system and can be effective on Crohn's disease (Kaskous et al., 2016).

\section{The camel milk effects on toxic metals}

Camel milk high content of antioxidant vitamins, magnesium, zinc and possible chelating effects on cadmium; reduced free radicals and oxidative stress in the red blood cells and improved toxic effects of cadmium (Dallak, 2009). Also, using of camel milk for 30 days improved toxic effects of aluminium by high increase in total erythrocytes, haemoglobin and haematocrit (Al-Hashem, 2009).

Treatment of lead acetate poisoned rats with camel milk recovered liver enzymes function (Al-Humaid et al., 2010). According to AlAsmari et al. (2014), the inhibiting effect of camel milk on oxidative stress and inflammation protect the structural integrity of hepatocyte membranes and regenerate destroyed hepatocytes.
The consumption of camel milk after irradiation could restore the liver function and content of alanine and aspartate aminotransferase and glutathione in rats (Mohamed \& Ali, 2008).

\section{Conclusions}

Due to camel milk containing vitamin $\mathrm{C}$ and protective proteins such as lactoferrin, immunoglobulins and lactoperoxidase, it has an important role in the healing of human serious diseases. Camel milk as raw, fresh and free of pathogens is effective on diabetes, food allergies, cancer, hepatitis, autism and enhances the immune system. However, about the medicinal effects of camel milk, still it needs to do more studies to prove these properties.

\section{Conflicts of interest}

The authors declare that they have no conflict of interests.

\section{Ethical approval}

All applicable institutional, national and international guidelines for the care and use of animals were followed.

\section{References}

Agrawal, R. P., Jain, S., Shah, S., Chopra, A., \& Agarwal, V. (2011). Effect of camel milk on glycemic control and insulin requirement in patients with type 1 diabetes: 2-years randomized controlled trial. European Journal Clinical Nutrition, 65, 1048-1052. https://doi.org/10.1038/ejen.2011.98

Agrawal, R. P., Budania, S., Sharma, P., Gupta, R., \& Kochar, D. K. (2007). Zero prevalence of diabetes in camel milk consuming Raica community of northwest Rajasthan, India. Diabetes Research and Clinical Practice, 76, 290e6.

Agrawal, R. P., Dogra, R., Mohta, N., Tiwari, R., Singhal, S., \& Sultania, S. (2009). Beneficial effect of 


\section{Mohammadabadi/ Basrah J. Agric. Sci., 33(2): 125-137, 2020}

camel milk in diabetic nephropathy. Acta Biomedica, 80, 131-134.

Agrawal, P. P., Swami, S. C., Beniwal, R., Kochar, D. K., Sahani, M. S., \& Tuteja, F. C. (2003). Effect of camel milk on glycemic control, risk factors and diabetes quality of life in type-1 diabetes: A randomized prospective controlled study. Journal of Camel Practice and Research, 10, 45-50.

Al-Asmari, A. K., Abbasmanthiri, R., Al-Elewi, A. M., Al-Omani, S., Al-Asmary, S., \& Al-Asmari, S.A. (2014). Camel milk beneficial effects on treating Gentamicin induced alterations in rats. Journal of Toxicology, 2014, 1-8.

Alavi, F., Salami, M., Emam-Djomeh, Z., Mohammadian, M. (2017). Nutraceutical Properties of Camel Milk. 451-468. In: Nutrients in Dairy and Their Implications for Health and Disease. Watson, R., Collier, R. \& Preedy, V. Academic Press, Elsevier. 490pp.

Al-Ayadhi, L. Y., \& Elamin, N. E. (2013). Camel milk as a potential therapy as an antioxidant in autism spectrum disorder (ASD). Evidence-Based Complementary and Alternative Medicine, 2013, 1-9. http://dx.doi.org/10.1155/2013/602834

Alhaj, O. A., Kanekanian, A., Peters, A. \& Tatham A. S. (2010). Hypocholesterolaemic effect of Bifidobacterium animalis subsp. lactis (Bb12) and trypsin casein hydrolysate. Food Chemistry, 123: 430435 .

Al-Hashem, F. (2009). Camel's milk protects against aluminum chloride-induced normocytic normocromic anemia, lipid peroxidation and oxidative stress in erythrocytes of white albino rats. American Journal of Biochemistry and Biotechnology, 5(3): 127-136.

Al-Humaid, A. I., Mousa, H. M., El-Mergawi, R. A., \& Abdel-Salam, A. M. (2010). Chemical composition and antioxidant activity of dates and date scamel-milk mixtures as a protective meal against lipid peroxidation in rats. American Journal of Food Technology., 5(1): 22-30.Doi:10.3923/ajft.2010.22.30

Ali, A. A., Alyan, A. A., \& Bahobail, A. S. (2013). Effect of fermented camel milk and cow milk containing (bifidobacteria) enriched diet in rats fed on cholesterol level. The Agricultural Science Research Journal, 3, $342 \mathrm{e} 6$.

Almahdy, O., El-Fakharany, E. M., El-Dabaa, E., Ng, T. B., \& Redwan, E. M. (2011). Examination of the activity of camel milk casein against hepatitis $\mathrm{C}$ virus (Genotype-4a) and its apoptotic potential in hepatoma and HeLa cell lines. Hepatitis Monthly, 11, 724-730. https://doi.org/10.5812/kowsar.1735143X.722.

Al-Majali, A. M., Bani-Ismail, Z., Al-Hami, Y., \& Nour, A. Y. (2007). Lactoferrin concentration in milk from camels (Camelus dromedaries) with and without subclinical Mastitis. The International Journal of Applied Research in Veterinary Medicine, 5, 120-124.

Al-Numair, K. S. (2010). Type II diabetic rats and the hypolipidemic effect of camel milk. The Journal of Food, Agriculture and Environment, 8, 77e81.

Al-Wabel, N. A., Hassan, A., Abbas, H., \& Muosa, H. (2012). Antiulcerogenic effect of camel milk against ethanol induced gastric ulcers in rats. Webmed. Central Vet. Med.

Alwan, A., \& Tarhuni, A. (2000). The effect of camel milk on Mycobacterium tuberculosis in man. $2^{\text {nd }}$ International Camelid Conference: Agroeconomics of Camelid Farming, Almaty, Kazakhstan, 8-12.

Aqiba, A. I., Kulyar, Muhammad, F. A., Ashfaq, Kh., Bhutta, Z. A., Shoaib M., \& Ahmed, R. (2019). Camel milk insuline: Pathophysiological and Molecular Repository. Trends in Food Science and Technology, 88: 497-504. https://doi.org/10.1016/j.tifs.2019.04.009

Ayoub, M. A., Palakkott, A. R., Ashraf, A., \& Iratni, R. (2018). The molecular basis of the anti-diabetic properties of camel milk. Diabetes Research and Clinical Practice, 146, 305-312. https://doi.org/ 10.1016/j.diabres.2018.11.006

Ayyash, M. (2016). Investigating the antimicrobial activity of pasteurized and raw camel milk against foodborne pathogens: Listeria monocytogenes and $E$. coli 0157:H7. Journal of Animal Science., 94: 239239. https://doi.org/10.2527/jam2016-0498

Bölte, S., \& Poustka, F. (2002). The relation between general cognitive level and adaptive behavior domains in individuals with autism with and without co-morbid mental retardation. Child Psychiatry and Human Development, 33, 165-172. 


\section{Mohammadabadi/ Basrah J. Agric. Sci., 33(2): 125-137, 2020}

Babilas. P.; Knie, U. \& Abels, C. (2012). Cosmetic and dermatologic use of alpha hydroxy acids. Journal der Deutschen Dermatologischen Gesellschaft., 10: 488$491 . \quad$ https://doi.org/10.1111/j.16100387.2012.07939.x

Baubekova, A., Kalimbetovaa, S. A., Akhmetsadykova, S. H., Konuspayeva, O., \& Faye, B. (2015). Comparison of D. Lactate and L. lactate content in cow and camel milk. In: Almaty, K., Konuspayeva, G. (Eds.). Proceeding 4th Conferences of ISOCARD, Silk Road Camel: The Camelids, main stakes for sustainable development, June 8-12, Science Practical Journal Veterinary, 2, 397-398.

Cardoso, R.R.; Santos, R.M.; Cardoso, C.R. \& Carvalho. M.O. (2010). consumption of camel's milk by patients intolerant to lactose. A preliminary study. Revista alergia Mexico, 57, 26-32.

Choi, S.K.; Park, K.D.; Kim, D.A.; Lee, D.W. \& KiM, Y.J. (2013). Preparation of camel milk liposome and its anti-aging effects. Journal of Society of cosmetic scientists of Korea., 40(2): 155-161. DOI: $10.15230 /$ SCSK.2014.40.2.155

Conesa, C.; Sanchez, L.; Rota, C.; Perez, M.; Calvo M. \& Farnoud S. (2008). Isolation of lactoferrin from milk of different species; calorimetric and antimicrobial studies. Comparative Biochemistry and Physiology., 150: 131-139. doi: 10.1016/j.cbpb.2008.02.005

Dallak, M. (2009). Camel's milk protects against cadmium chloride-induced hypochromic microcytic anemia and oxidative stress in red blood cells of white albino rats. American Journal of Pharmacology and Toxicology., $\quad$ 4(4): 136-143. DOI: 10.3844/ajptsp.2009.136.143

Darwish, H.A.; Raboh, N.R.A. \& Mahdy, A. (2012). Camel's milk alleviates alcohol-induced liver injury in rats. Food and Chemical Toxicology., 50(5): 13771383. doi: 10.1016/j.fct.2012.01.016.

Ebaid, H.; Abdel-Salam, B.; Hassan, I.; Al-Tamimi, J.; Metwalli, A. \& Alhazza, I. (2015). Camel milk peptide improves wound healing in diabetic rats by orchestrating the redox status and immune response. Lipids in Health and Disease., 14, 132. https://doi.org/ 10.1186/s12944-015-0136-9
Elagamy, E.I.; Nawar, M.; Shamsia. S.M.; Awad, S. \& Haenlein, G.F. (2009). Are camel milk proteins convenient to the nutrition of cow milk allergic children? Small Ruminant Research., 82: 1-6. https://doi.org/10.1016/j.smallrumres. 2008.12.016

Elayan, A. A., Sulieman, A. E., \& Saleh, F.A. (2008). The hypocholesterolemic effect of Gariss and Gariss containing Bifid bacteria in rats fed on a cholesterolenriched diet. Asian Journal of Biochemistry., 3, 4347. 10.3923/ajb.2008.43.47

El-Fakharany, E. M., Abedelbaky, N., Haroun, B. M., Sanchez, L., Redwan, N. A. E., \& Redwan, M. (2012). Anti-infectivity of camel polyclonal antibodies against hepatitis $\mathrm{C}$ virus in Huh 7.5 hepatoma. Virology Journal., 16, 201-211.

El-Fakharany, E. M., Sánchez, L., Al-Mehdar, H. A., \& Redwan, E. M. (2013). Effectiveness of human, camel, bovine and sheep lactoferrin on the hepatitis $\mathrm{C}$ virus cellular infectivity: comparison study. Virology Journal., $\quad 10, \quad 1$. https://virologyj.biomedcentral.com/articles/10.1186/1 743-422X-10-199

Farah, Z. (1993). Composition and characteristics Camel milk. Journal of Dairy Research., 60, 603-26. https://doi.org/10.1017/S0022029900027953

Gader, A. G. M. A. \& Alhaider, A. A. (2016). The unique medicinal properties of camel products: A review of the scientific evidence. Journal of Taibah University Medical Sciences., 11, 98-103. https://doi.org/10.1016/j.jtumed.2015.12.007

Galali, Y., \& Al-Dmoor, A. (2019). Miraculous Properties of Camel Milk and Perspective of Modern Science. Journal of Family Medicine and Disease Prevention., 5: 95. https://doi.org/10.23937/24695793/1510095.

Gizachew, A.; Teha, J. \& Birhanu, T. (2014). Review on medicinal and nutritional values of camel milk. Natural Sciences., 12(12): 35-40.

Gul, W., Farooq, N., Anees, D.; Khan, U., \& Rehan, F. (2015). Camel Milk: A boon to mankind. International Journal of Research Studies in Biosciences., 11, 23-29.

Habib, H. M., Ibrahim, W. H., Schneider-Stock, R., \& Hassan, H.M. (2013). Camel milk lactoferrin reduces 


\section{Mohammadabadi/ Basrah J. Agric. Sci., 33(2): 125-137, 2020}

the proliferation of colorectal cancer cells and exerts antioxidant and DNA damage inhibitory activities. Food Chemistry, 141, 148-152. https://doi.org/10.1016/j.foodchem.2013.03.039.

Hamad, E.M.; Abdel-Rahim, E.A.;\& Romeih, E.A. (2011). Beneficial effect of camel milk on liver and kidneys function in diabetic Sprague-Dawley rats. International Journal of Dairy Science., 6, 190-197.

Hoelzer, W.; Muyldermans, S. \& Wernery, U. (1998). A note on camel IgG antibodies. Journal of Camel Practice and Research., 5: 187-188.

Jilo, K. \& Tegegne, D. (2016). Chemical Composition and Medicinal Values of Camel Milk. International Journal of Research Studies in Biosciences., 4, 13-25.

Kaskous, S. (2016). Importance of camel milk for human health. Emirates Journal of Food Agriculture, 26, 158-163. https://doi.org/10.9755/ejfa.2015-05-296

Katz, Y.; Goldberg, M.R.; Zadik-Mnuhin, G.; Leshno, M. \& Heyman, E. (2008). Cross-sensitization between milk proteins: reactivity to a "kosher" epitope? Israel Medical Association Journal., 10, 85-88. https://pubmed.ncbi.nlm.nih.gov/18300584/

Korashy, H.M.; Maayah, Z.H.; Abd-Allah, A.R.; ElKadi, A.O. \& Alhaider, A.A. (2012). Camel milk triggers apoptotic signaling pathways in human hepatoma HepG2 and breast cancer MCF7 cell lines through transcriptional mechanism. Journal of Biomedicine and Biotechnology., 2012: 9pp..

Korish, A. A., \& Arafah, M.M. (2013). Camel milk ameliorates steatohepatitis, insulin resistance and lipid peroxidation in experimental non-alcoholic fatty liver disease. BMC Complementary and Alternative Medicine., 13, 1. https://doi.org/ 10.1186/1472-688213-264.

Levy, A., Steiner, L., \& Yagil, R. (2013). Camel milk: disease control and dietary laws. Journal of Health Sciences., 1: 48- 53.

Li, H., \& Papadopoulos, V. (1998). Peripheral-type benzodiazepine receptor function in cholesterol transport. Identification of a putative cholesterol recognition/interaction amino acid sequence and consensus pattern. Endocrinology., 139, 4991-4997. DOI:10.1210/endo.139.12.6390
Mohamad, R.H.; Zekry, Z.K.; Al-Mehdar, H.A.; Salama, O.; El-Shaieb, S.E. \& El- Basmy, A.A. (2009). Camel milk as an adjuvant therapy for the treatment of type 1 diabetes: Verification of a traditional ethnomedical practice. Journal of Medicinal Food., 12, 461-465. https://doi.org/10.1089/jmf.2008.0009.

Mohamed, N. \& Ali, S. (2008). Camel milk modulates gamma radiation induced biochemical hazardous changes in rats. Radiation Research., 40(4): 10131026. doi: $10.1017 / \mathrm{dmp} .2018 .16$

Molitch, M.E.; Defronzo, R.A.; Franz, M.J. \& Keane, W.F. (2004). Nephropathy in diabetes. Diabetes Care., 27, S79. https://doi.org/10.2337/diacare.27.2007.S79

Morin, D.E.; Rowan, L.L. \& Hurley, W.L. (1995). Comparative study of proteins, peroxidase activity and $\mathrm{N}$-acetyl-ß3-Dglucosaminidase activity in llama milk. Small Ruminant Research., 17, 255-261. https://doi.org/10.1016/0921-4488(95)00679-F

Mullaicharam, A.R. (2014). A review on medicinal properties of camel milk. World Journal of Pharmaceutical Sciences., 2, 237-242.

Muyldermans, S.; Cambillau, C. \& Wyns, L. (2001). Recognition of antigens by single-domain antibody fractions: the superfluous luxury of paired domains. Trends in Biochemical Sciences., 26, 230-235. https://doi.org/10.1016/s0968-0004(01)01790-x

Panwar, R., Grover, C. R.; Kumar, V., Ranga, S. \& Kuma, N. (2015). Camel milk: Natural medicine Boon to dairy industry". Principal Scientist; Ph. D. Scholars; Dairy Microbiology Division, ICARNational Dairy Research Institute, Karnal, (Haryana), $1-10$.

Quan, S.; Tsuda, H. \& Miyamoto, T. (2008). Angiotensin I-converting enzyme inhibitory peptides in skim milk fermented with Lactobacillus helveticus 130B4 from camel milk in Inner Mongolia, China. Journal of the Science of Food and Agriculture., 88, 2688-2692. https://doi.org/10.1002/jsfa.3394

Redwan, E.R.M. \& Tabll, A. (2007). Camel lactoferrin markedly inhibits hepatitis $\mathrm{C}$ virus genotype 4 infection of human peripheral blood leukocytes. Journal of Immunoassay and Immunochemistry., 28: 267-277. https://doi.org/10.1080/15321810701454839 


\section{Mohammadabadi/ Basrah J. Agric. Sci., 33(2): 125-137, 2020}

Rasheed, Z. (2011). Monitoring biodegradative enzymes with nanobodies raised in Camelus dromedaries with mixtures of catabolic proteins. Environmental Microbiology., $\quad$ 13: 960-974. https://doi.org/10.1111/j.1462-2920.2010.02401.x

Rasheed, Z. (2017). Medicinal values of bioactive constituents of camel milk: A concise report. International Journal of Health Sciences., 11(5):1-2.

Restani, P.; Gaiaschi, A.; Plebani, A.; Beretta, B.; Cavagni, G. \& Galli, C. (1999). Cross reactivity between milk proteins from different animal species. Clinical and Experimental Allergy., 29: $997-$ 1004.https://doi.org/10.1046/j.13652222.1999.00563.x

Russo, A.J. (2009). Decreased serum Cu/Zn SOD in children with autism. Nutrition and Metabolic Insights., 2: 27-35. DOI: 10.4137/NMI.S3733

Salami, M.; Moosavi-Movahedi, A.A.; MoosaviMovahedi, F.; Ehsani, M.R. \& Yousefi, R. (2011). Biological activity of camel milk casein following enzymatic digestion. Journal of Dairy Research., 78: 471-478. https://doi.org/10.1017/S0022029911000628

Saltanat, H.; Li, H.; Xu, Y.; Wang, J.; Liu, F. \& Geng, XH. (2009). The influences of camel milk on the immune response of chronic hepatitis B. Xi bao yu fen zi mian yi xue za zhi=Chinese journal of cellular and molecular immunology., 25(5): 431-433.

Salwa, M.Q. \& Lina, A.K. (2010). Antigenotoxic and anticytotoxic effect of camel milk in mice treated with cisplatin. Saudi Journal of Biological Sciences., 17(2): 159-166. https://doi.org/10.1016/j.sjbs.2010.02.010

Sboui, A.; Khorchani, T. \& Djegham, M. (2010). Antidiabetic effect of camel milk in alloxan-induced diabetic dogs: A dose-response experiment. Journal of Animal Physiology and Animal Nutrition., (Berl), 94: 540-546. https://doi.org/10.1111/j.14390396.2009.00941.x

Shabo. Y. \& Yagil, R. (2005). Etiology of autism and camel milk as therapy. International Journal on
Disability and Human Development., 4: 67-70. https://doi.org/10.1515/IJDHD.2005.4.2.67

Shamsia, S.M. (2009). Nutritional and therapeutic properties of camel and human milks. Journal of Genetics and Molecular Biology., 1: 52.

Shori, A.B. (2015). Camel milk as a potential therapy for controlling diabetes and its complications: A review of in vivo studies. Journal of Food and Drug Analysis., 23: 609618. https://doi.org/10.1016/j.jfda.2015.02.007.

Stahl, T. (2005). Vitamingehalte und Fettsäuremuster in Kamelmilch. Ph. D Thesis. Univ. Giessen, 147pp.

Wernery, R. \& Yagil, R. (2012). Medicinal properties in camel milk for treatment of Epidemic Diseases. Proc. 3rd ISOCARD Int. Conf., 29 $9^{\text {th }}$ January- $1^{\text {st }}$ February 2012 Muscat, Sultanate of Oman. 225-227.

Wernery, U. (2006). Camel milk, the white gold of the desert. J. Camel Pract. Res., 13(1): 15-26. https://www.researchgate.net/publication/279892395_ Camel_milk_the_white_gold_of_the_desert

Wild, S., Roglic, G., Green, A., Sicree, R., \& King, H. (2004). Global prevalence of diabetes: Estimates for the year 2000 and projections for 2030. Diabetes Care, 2, 1047-1053.

Yagil, R. (2013). Camel milk and its unique antidiarrheal properties. Israel Medical Association Journal., 15: 35-36.

Yagil, R. (2017). Cosmeceuticals: Camel and other milk --Natural Skin Maintenance. Rec Advances.309-338 In Keservani, R.K.; Sharma, A.K. \& Kesharwani, R.K. (Eds.). Recent Advances in Drug Delivery Technology IGI Global. 510pp. https://doi.org/10.4018/978-1-5225-0754-3.ch011

Yateem, A.; Balba, M.T.; Al-Surrayai, T.; Al-Mutairi, B. \& Al-Daher, R. (2008). Isolation of lactic acid bacteria with probiotic potential from camel milk. International Journal of Dairy Science., 3: 194-199. 
Mohammadabadi/ Basrah J. Agric. Sci., 33(2): 125-137, 2020

حليب الابل كعلاج مذهل للمشكلات الصحية: مقالة مراجعيه

\section{طاهره محمد آبادي}

قسم علم الحيوان، كلية علم الحيوان التقانات الغذائية، جامعة خوزستان، الاهواز ، ايران

المستخلص: يعد حليب الإبل ذو فوائد فريدة لصحة الإنسان. وان البروتينات هي المكون الرئيسي لحليب الابل الذي تعطيه مميزات فريدة وتؤثر بشكل فعال على قيمته الغذائية. بسبب نقص البيتا لاكتوكلوبيولين في حليب الإبلل ، لذا قد يكون بديل مناسب للحليب البشري. ان حليب الإبل غني بفيتامين C والمنغنيز والحديد. كما يحتوي على كمية كبيرة من الأحماض الدهنية غير المشبعة و الكلوبيولينات المناعية والبروتينات المشابهة للأنسولين والإنزيمات الواقية مثل اللاكتوفيرين وللايسوزايم. يُعد اللاكتوفيرين ذو تأثيرات أو

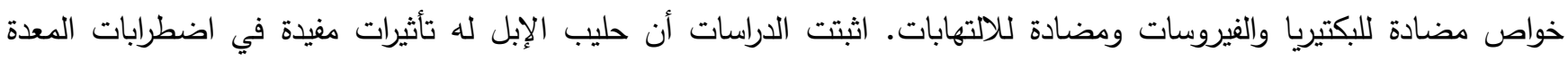
والأمعاء وحساسية الطعام وداء السكري والسرطان والتوحد والتهاب الكبد الفيروسي. يحتوي حليب الإبل على البروتينات المشابهة


كلوبيولين مناعي صغير الحجم الذي يقوي جهاز المناعة. إن حليب الإبل يقلل من كمية الكوليسترول في الدم ويقي من مرض الصدفية ويساهم في شفاء الآتهابات ومرض السل. لذا قد يكون حليب الإبل فعالا كمجزة فريدة في العديد من المشكلات الصحية البشرية وخاصة القلب والأوعية الدموية. لذلك فهو ليس طعامًا فقط وانما علاجاً مدهثاً للمشكلات الصحية البشرية. الكلمات المفتاحية: حليب الابل، الصحة،لاكتوفيرين، الفوائد الطبية. 